(c) American Dairy Science Association, 2003.

\title{
Effects of Propylene Glycol or Fat Drench on Plasma Metabolites, Liver Composition, and Production of Dairy Cows During the Periparturient Period ${ }^{1}$
}

\author{
M. M. Pickett ${ }^{2}$, M. S. Piepenbrink, and T. R. Overton \\ Department of Animal Science \\ Cornell University, Ithaca, NY 14853
}

\begin{abstract}
Forty-eight Holstein cows were used to determine the effects of short-term oral drenches of propylene glycol (PG) and Ca-soaps of palm oil fatty acids (fat) on plasma concentrations of key metabolites, liver composition, and milk production during the first 3 wk of lactation. Treatments $(2 \times 2$ factorial arrangement) given orally once daily for the first $3 \mathrm{~d}$ postpartum were water (control), $500 \mathrm{ml}$ of PG, $454 \mathrm{~g}$ of fat, or $500 \mathrm{ml}$ of PG plus $454 \mathrm{~g}$ of fat. All treatments were administered as a total volume of $1.9 \mathrm{~L}$. Administration of PG decreased concentrations of nonesterified fatty acids (NEFA) in plasma during the first $7 \mathrm{~d}$ and the first $21 \mathrm{~d}$ postpartum and tended to decrease concentrations of $\beta$-hydroxybutyrate during the first $7 \mathrm{~d}$ postpartum. Concentrations of insulin in plasma were not affected by treatment. Administration of either $\mathrm{PG}$ or fat increased plasma glucose and liver glycogen concentrations compared to the control or PG plus fat treatments. Concentrations of triglycerides in liver were not affected by treatment. Administration of PG did not affect dry matter intake or milk yield and composition during the first $3 \mathrm{wk}$ postpartum; however, cows drenched with fat tended to have lower dry matter intake and milk yield during the first $3 \mathrm{wk}$ of lactation. Short-term drenching of $P G$ effectively decreased NEFA concentrations in plasma during early lactation; however, data do not support administration of fat via drench to early lactation cows and concurrent administration of dietary fat appears to blunt the metabolic response of cows to PG.
\end{abstract}

Received October 18, 2002.

Accepted December 9, 2002.

Corresponding author: T. R. Overton; e-mail: tro2@cornell.edu.

${ }^{1}$ Supported in part by a gift from Bioproducts, Inc., Fairlawn, $\mathrm{OH}$, and in part by the Cornell University Agricultural Experiment Station federal formula funds, Project No. 127453 received from Cooperative State Research, Education, and Extension Service, U.S. Department of Agriculture. Any opinions, findings, conclusions, or recommendations expressed in this publication are those of the authors and do not necessarily reflect the view of the U.S. Department of Agriculture.

${ }^{2}$ Current address: 324 Henning Building, The Pennsylvania State University, University Park 16802.
(Key words: propylene glycol, fat, periparturient cow)

Abbreviation key: $\mathbf{P G}=$ propylene glycol, $\mathbf{T G}=$ triglyceride(s).

\section{INTRODUCTION}

The periparturient period is characterized by tremendous metabolic adaptation of the cow from the demands of late pregnancy to those of early lactation; failure of the cow to successfully conduct these adaptations results in the occurrence of metabolic disorders, poor reproductive performance, and decreased milk production during the ensuing lactation (Bell, 1995; Grummer, 1995; Drackley, 1999). One of the major metabolic adaptations involves the mobilization of adipose tissue depots to supply energy to support milk production, given that energy intake is insufficient to meet energy requirements. Mobilization of these adipose depots results in the release of NEFA into the bloodstream (Emery et al., 1992). The NEFA are used as a fuel source by muscle, incorporated into milk fat, and taken up by the liver, apparently in proportion to their supply (Pullen et al., 1989; Bell, 1995). Concentrations of NEFA in the bloodstream start to increase approximately $1 \mathrm{wk}$ prior to parturition and peak 3 to $5 \mathrm{~d}$ after parturition before returning to lower concentrations by 14 to $21 \mathrm{~d}$ postpartum (Bertics et al., 1992; VazquezAnon et al., 1994). As indicated above, NEFA are used for oxidative metabolism by some tissues and are incorporated into milk fat; however, excessive mobilization of NEFA results in accumulation of triglycerides (TG) in the liver and is detrimental to overall cow health and performance (Grummer, 1993; Drackley et al., 2001). Therefore, research efforts have focused on determining methods to decrease the release of NEFA from adipose tissue.

Propylene glycol (PG) is a glucogenic precursor that has been used for many years for both treatment and prevention of ketosis before and after parturition. Several experiments have been conducted to evaluate the effects of PG on metabolism. These studies differ in quantity, timeframe, and method of delivery of PG. 
Short-term experiments using nonlactating cattle determined that administration of $\mathrm{PG}$ as an oral drench decreased concentrations of NEFA and BHBA in plasma (Grummer et al., 1994; Christensen et al., 1997). Studer et al. (1993) determined that $1 \mathrm{~L}$ of PG administered during the last $10 \mathrm{~d}$ before parturition increased concentrations of glucose and insulin and decreased concentrations of NEFA and BHBA in plasma before parturition. After parturition, cows administered $P G$ prepartum tended to have lower concentrations of NEFA and had significantly decreased liver TG accumulation. Burhans et al. (1997) drenched $250 \mathrm{ml}$ of PG twice daily from $\mathrm{d} 21$ prepartum to $\mathrm{d} 21$ postpartum and reported no effect of PG on plasma NEFA and BHBA concentrations prior to parturition. After parturition, PG drenches resulted in significantly decreased concentrations of NEFA and BHBA in plasma.

Although, in general, these strategies have proven to be effective in decreasing concentrations of NEFA and BHBA in plasma of dairy cows during the transition period, they are very labor intensive. Of greater interest would be shorter-term drenching programs that would coincide with intensive monitoring programs in place on many dairy farms. Stokes and Goff (2001) determined that a 2-d drench beginning at parturition increased milk yield and decreased concentrations of NEFA in plasma of cows on a commercial dairy farm. Data are not available to more fully evaluate shortterm drenching programs with PG.

Some researchers have proposed that dietary fat, either included in the diet or as a drench, may help to decrease concentrations of NEFA and help to prevent occurrence of ketosis (Kronfeld, 1982). Dietary fat is absorbed into the lymphatic system and does not pass first through the liver. This fat can provide energy for peripheral tissues and the mammary gland. Their hypothesis is that this would in turn decrease mobilization of body fat and decrease NEFA concentrations. Data are not available in the published literature to evaluate this practice. In general, feeding dietary fat to dairy cows during the transition period does not appear to decrease NEFA concentrations in periparturient dairy cows (Drackley, 1999). Anecdotal reports from various practitioners in the dairy industry have indicated beneficial effects of either feeding dietary fat or drenching dietary fat to fresh cows; however, to our knowledge these reports are not supported by controlled experimentation. The metabolic effects of administering dietary fat as an oral drench are not known.

The objective of this experiment was to determine whether a short-term (3-d) drenching strategy of PG, fat, or a combination of the two beginning at calving would be effective in modulating concentrations of metabolites in plasma and liver composition. We hypothe- sized that short-term drenching of PG, fat, or a combination would be beneficial to postpartum cow health by increasing plasma glucose concentrations, decreasing NEFA and BHBA concentrations in plasma, and decreasing TG accumulation in the liver.

\section{MATERIALS AND METHODS}

\section{Experimental Animals and Treatments}

All procedures using animals were approved by the Cornell University Institutional Animal Care and Use Committee prior to beginning the experiment. Fortyeight Holstein dairy cows were utilized in a completely randomized design with four treatments. The cows utilized in this experiment consisted of multiparous $(\mathrm{n}=$ 36) and primiparous $(\mathrm{n}=12)$ animals. At calving, cows were assigned to one of four drench treatments. Treatment assignments were random within parity.

Drenches were given initially within $24 \mathrm{~h}$ of calving between 0900 and $1100 \mathrm{~h}$. The subsequent two drenches were given at the same time on the following $2 \mathrm{~d}$. The four treatments consisted of water (control), $500 \mathrm{ml} \mathrm{PG}$, $0.454 \mathrm{~kg}$ rumen-protected fat supplement (fat; EnerG II-Bioproducts, Inc., Fairlawn, OH), and $500 \mathrm{ml}$ of PG plus $0.454 \mathrm{~kg}$ fat supplement (PG+Fat). The amount of PG administered was based on previous research that demonstrated decreased postpartum concentrations of NEFA and BHBA in plasma using a $500 \mathrm{ml} / \mathrm{d}$ dose (Burhans et al., 1997). The amount of fat administered was based on the amount used to treat cows with clinical fatty liver (W. Chalupa, University of Pennsylvania, personal communication). Treatment amounts were chosen based on practical industry application rather than on an isocaloric basis. Treatments were combined with water to a complete volume of $1.9 \mathrm{~L}$ and vigorously stirred immediately before administration. Treatments were administered via esophageal tubing inserted directly into the rumen through a stainless steel speculum. Placement of the distal end of the tubing in the rumen liquor was confirmed by blowing on the proximal end of the tubing and listening for gas bubbles in the rumen using a stethoscope. After administration of the 1.9-L volume, an additional $0.5 \mathrm{~L}$ of water was used to rinse the container and tubing to ensure that the animal received the complete dose.

\section{Experimental Procedures, Sampling, and Analysis}

Prior to parturition, all cows were housed in a common pen and received the same close-up dry cow diet at $1200 \mathrm{~h}$ daily. During the dry period, group intakes were measured daily and feed refusals were collected. Cows were fed for ad libitum intake both prepartum and postpartum. Prepartum and postpartum diet com- 
Table 1. Ingredient and chemical composition of the prepartum and postpartum diets (DM basis).

\begin{tabular}{lcc}
\hline Item & Prepartum & Postpartum \\
\hline Ingredient & & \\
Corn silage, \% & 38.1 & 30.9 \\
Hay crop silage, \% & 12.0 & 15.5 \\
Grass hay, \% & 12.6 & $\ldots .6$ \\
Alfalfa hay, \% & 21.1 & 24.6 \\
Ground shelled corn, \% & 4.0 & 3.7 \\
Soybean meal (47.5\% CP), \% & 5.6 & 7.7 \\
Expeller soybean meal, \% & 3.6 & 5.6 \\
Whole cottonseeds, \% & $\ldots .9$ & 0.5 \\
Sodium bicarbonate, \% & 2.9 & 2.9 \\
Mineral and vitamin mix, $1,2 \%$ & & \\
Chemical & 15.7 & 16.4 \\
CP, \% & 35.6 & 34.3 \\
NDF, \% & 23.3 & 22.0 \\
ADF, \% & 43.6 & 43.4 \\
NFC, \% & 4.3 & 4.8 \\
EE, \% & 1.58 & 1.63 \\
NE, Mcal/kg & 0.92 & 1.07 \\
Ca, \% & 0.45 & 0.49 \\
P, \% & 0.45 & 0.32 \\
Mg, \% & 1.48 & 1.40 \\
K, \%
\end{tabular}

${ }^{1}$ The mix fed prepartum contained $11.9 \% \mathrm{Ca}, 6.2 \% \mathrm{Mg}, 4.3 \% \mathrm{Na}$, $6.6 \%, \mathrm{Cl}, 1.55 \% \mathrm{~S}, 32 \mathrm{mg} / \mathrm{kg} \mathrm{Co}, 302 \mathrm{mg} / \mathrm{kg} \mathrm{Cu}, 760 \mathrm{mg} / \mathrm{kg} \mathrm{Fe}, 32 \mathrm{mg} /$ $\mathrm{kg} \mathrm{I}, 1126 \mathrm{mg} / \mathrm{kg} \mathrm{Mn}, 16 \mathrm{mg} / \mathrm{kg}$ Se, $1489 \mathrm{mg} / \mathrm{kg} \mathrm{Zn}, 146 \mathrm{IU} / \mathrm{g}$ of vitamin A, $59 \mathrm{IU} / \mathrm{g}$ of vitamin D, and $2594 \mathrm{IU} / \mathrm{g}$ of vitamin $\mathrm{E}$.

${ }^{2}$ The mix fed postpartum contained $20.0 \% \mathrm{Cl}, 18.0 \% \mathrm{Na}, 12.0 \% \mathrm{Ca}$, $8.0 \% \mathrm{~S}, 7.5 \% \mathrm{Mg}, 1.0 \% \mathrm{~K}, 0.01 \% \mathrm{P}, 4800 \mathrm{mg} / \mathrm{kg} \mathrm{Zn}, 4000 \mathrm{mg} / \mathrm{kg} \mathrm{Mn}$, $2900 \mathrm{mg} / \mathrm{kg} \mathrm{Fe}, 700 \mathrm{mg} / \mathrm{kg} \mathrm{Cu}, 60 \mathrm{mg} / \mathrm{kg} \mathrm{Co}, 550 \mathrm{IU} / \mathrm{g}$ of vitamin A, $132 \mathrm{IU} / \mathrm{g}$ of vitamin D, and $2970 \mathrm{IU} / \mathrm{g}$ of vitamin $\mathrm{E}$.

${ }^{3} 100-((\mathrm{NDF}-\mathrm{NDFCP})+\mathrm{CP}+\mathrm{Ash}+\mathrm{EE})$.

positions are reported in Table 1. At calving, animals were moved to individual tie stalls and fed a TMR at $1200 \mathrm{~h}$ daily. Amounts of feed offered and refused were recorded daily from calving until $21 \mathrm{~d}$ postpartum for individual cows. Samples of the feeds and TMR were collected on a weekly basis and dried to static weight at $60^{\circ} \mathrm{C}$. Dry matter intakes were calculated based on the amounts of feed offered and refused, together with the DM content of the TMR. Monthly composite samples of individual feed ingredients were analyzed for $\mathrm{DM}, \mathrm{OM}, \mathrm{CP}$, ether extract, ash, soluble CP, ADF, NDF, lignin, ADF-CP, and NDF-CP by wet chemistry procedures (DairyOne Laboratories, Ithaca, NY).

Cows were milked three times daily from calving through d 21 postcalving, and individual milk weights were measured at each milking. Weekly composite samples were prepared from milk samples obtained from three consecutive milkings. Composite milk samples were analyzed for contents of fat, true protein, lactose, total solids, urea N, and average SCC by midinfrared spectroscopy (DairyOne Laboratories, Ithaca, NY).

Body weights were measured weekly and BCS were assigned weekly by two scorers starting approximately 2 wk prior to calving. Body condition was scored on a scale of 1 to 5 ( $1=$ thin, 5 = overweight; Wildman et al., 1982).

Blood samples were collected by venipuncture of the coccygeal vein/artery using heparinized Vacutainer tubes (Becton Dickson, Franklin Lakes, NJ). Samples were collected once weekly at $1100 \mathrm{~h}$ from all cows in the dry cow pen. Each cow was bled a minimum of twice precalving, and no cows were bled more than three times. After calving, blood was sampled daily (0800 h) from the day of calving until $7 \mathrm{~d}$ postpartum and every other day until $21 \mathrm{~d}$ postpartum. All blood samples were obtained prior to feeding and treatment administration. Blood samples were placed on ice immediately following collection. Plasma was harvested following centrifugation at $2060 \times \mathrm{g}$ for $15 \mathrm{~min}$ at $5^{\circ} \mathrm{C}$. Plasma was transferred into microfuge tubes and stored at $-20^{\circ} \mathrm{C}$ until analysis. Plasma was thawed and analyzed for concentrations of glucose (kit 510-A, Sigma Diagnostics, St. Louis, MO), NEFA (NEFA-C kit, WAKO Chemical Co., Dallas, TX), using modifications as published by McCutcheon and Bauman (1986), and BHBA (kit 310-UV, Sigma). Plasma insulin concentrations were analyzed by radioimmunoassay using antibodies from the Linco insulin RIA kit (Linco Research, Inc., St. Louis, MO) and bovine insulin (Elanco Animal Health, Greenfield, IN) for iodination and standards (Ehrhardt et al., 2001). Inter- and intraassay CV were 15 and $11 \%$, respectively.

Liver samples were obtained from each cow on $d 7$ postpartum by percutaneous trochar biopsy (Veenhuizen et al., 1991). This timepoint was chosen because it is within the period of relatively rapid hepatic infiltration with lipid (Grummer, 1993), yet we believed that it was sufficiently downstream from the cessation of treatment that differences observed would be biologically relevant. Liver samples were blotted to remove excess blood and connective tissue, then snap frozen by immersion in liquid $\mathrm{N}^{2}$. Samples were stored at $-20^{\circ} \mathrm{C}$ until analysis for concentrations of triglycerides (Rukkwamsuk et al., 1999, as modified by Piepenbrink et al., 2003) and glycogen (Lo et al., 1970).

\section{Statistical Analyses}

Prepartum values for BW, BCS, plasma metabolites, and plasma insulin were reduced to means and utilized as covariates during analysis of covariance applied to their respective postpartum measurements. Milk yield and DMI were reduced to weekly means before analysis. Analysis of variance for blood and performance measurements was conducted during both $\mathrm{d} 2$ through 7 postpartum and $d 2$ through 21 postpartum using the MIXED procedure of SAS (2001) for a completely randomized design with repeated measures (Littell et al., 
Table 2. Least squares means and standard errors for concentrations of metabolites and insulin in plasma from d 2 through 7 and d 2 through 21 postpartum for cows administered either a water control, propylene glycol (PG), fat, or a combination (PG+Fat) via oral drench during the first $3 \mathrm{~d}$ of lactation.

\begin{tabular}{|c|c|c|c|c|c|c|c|c|}
\hline \multirow[b]{2}{*}{ Item } & \multicolumn{4}{|c|}{ Treatment } & \multirow[b]{2}{*}{ SEM } & \multicolumn{3}{|c|}{ Effect, P } \\
\hline & Control & PG & Fat & PG+Fat & & PG & Fat & $P G \times$ fat \\
\hline $\begin{array}{l}\text { NEFA, } \mu \mathrm{Eq} / \mathrm{L} \\
\text { d } 2 \text { through } 7 \\
\text { d } 2 \text { through } 21\end{array}$ & $\begin{array}{l}695 \\
643\end{array}$ & $\begin{array}{l}571 \\
503\end{array}$ & $\begin{array}{l}684 \\
602\end{array}$ & $\begin{array}{l}582 \\
558\end{array}$ & $\begin{array}{l}60 \\
43\end{array}$ & $\begin{array}{l}0.06 \\
0.03\end{array}$ & $\begin{array}{l}0.99 \\
0.87\end{array}$ & $\begin{array}{l}0.86 \\
0.24\end{array}$ \\
\hline $\begin{array}{l}\text { BHBA, mg/dl } \\
\text { d } 2 \text { through } 7 \\
\text { d } 2 \text { through } 21\end{array}$ & $\begin{array}{l}10.1 \\
10.8\end{array}$ & $\begin{array}{l}8.2 \\
8.1\end{array}$ & $\begin{array}{l}8.8 \\
9.4\end{array}$ & $\begin{array}{l}8.1 \\
9.4\end{array}$ & $\begin{array}{l}0.8 \\
1.1\end{array}$ & $\begin{array}{l}0.11 \\
0.20\end{array}$ & $\begin{array}{l}0.39 \\
0.97\end{array}$ & $\begin{array}{l}0.49 \\
0.22\end{array}$ \\
\hline $\begin{array}{l}\text { Glucose, mg/dl } \\
\text { d } 2 \text { through } 7 \\
\text { d } 2 \text { through } 21\end{array}$ & $\begin{array}{l}36.3 \\
36.5\end{array}$ & $\begin{array}{l}38.3 \\
37.6\end{array}$ & $\begin{array}{l}39.4 \\
39.1\end{array}$ & $\begin{array}{l}37.0 \\
36.8\end{array}$ & $\begin{array}{l}1.0 \\
0.8\end{array}$ & $\begin{array}{l}0.88 \\
0.45\end{array}$ & $\begin{array}{l}0.38 \\
0.27\end{array}$ & $\begin{array}{l}0.04 \\
0.03\end{array}$ \\
\hline $\begin{array}{l}\text { Insulin, ng/ml } \\
\text { d } 2 \text { through } 7 \\
\text { d } 2 \text { through } 21\end{array}$ & $\begin{array}{l}0.57 \\
0.66\end{array}$ & $\begin{array}{l}0.63 \\
0.72\end{array}$ & $\begin{array}{l}0.50 \\
0.63\end{array}$ & $\begin{array}{l}0.52 \\
0.61\end{array}$ & $\begin{array}{l}0.07 \\
0.06\end{array}$ & $\begin{array}{l}0.61 \\
0.79\end{array}$ & $\begin{array}{l}0.21 \\
0.23\end{array}$ & $\begin{array}{l}0.80 \\
0.56\end{array}$ \\
\hline
\end{tabular}

1998). The model contained the effects of PG administration, fat administration, the interaction of $P G$ and fat administration, time, and two- and three-way interactions of these effects with time. Liver measurements were subjected to analysis of variance for a completely randomized design using the MIXED procedure of SAS (2001). The model contained the effects of PG administration, fat administration, and the interaction of $P G$ and fat administration. Significance was declared at $P$ $<0.05$ and trends toward a significant difference at 0.05 $<P<0.15$. Least squares means are presented throughout.

\section{RESULTS AND DISCUSSION}

Concentrations of NEFA in plasma tended $(P<0.06)$ to be decreased during $\mathrm{d} 2$ through 7 and were decreased $(P<0.03)$ during $\mathrm{d} 2$ through 21 of lactation by administration of $\mathrm{PG}$ during the first $3 \mathrm{~d}$ of lactation; however, fat administration did not affect concentrations of NEFA in plasma, and the interaction of these main effects was not significant (Table 2, Figure 1). Previous studies reported decreased plasma NEFA concentrations when PG was administered during the transition period (Studer et al., 1993; Grummer et al., 1994; Formigoni et al., 1996; Burhans et al., 1997; Christensen et al., 1997; Stokes and Goff, 2001). In most of these studies, treatments were administered for longer than $3 \mathrm{~d}$; our data suggest that blunting the peak in NEFA (Figure 1) likely results in carryover effects on subsequent concentrations of NEFA. Our data support those of Stokes and Goff (2001), who determined that a 2d drench of PG decreased concentrations of NEFA in plasma compared with controls or cows drenched with Ca-propionate.

Administration of fat in this experiment did not affect concentrations of NEFA in plasma during the first 21 $\mathrm{d}$ of lactation (Table 2). It was hypothesized that dietary fat decreases NEFA mobilization by providing energy to the peripheral tissues and muscles via the lymphatic system (Kronfeld, 1982). Our results do not support this hypothesis.

Concentrations of BHBA in plasma tended $(P<0.11)$ to decrease during d 2 through 7 postpartum when PG was administered during the first $3 \mathrm{~d}$ of lactation; however, BHBA was not affected significantly by treatment during $d 2$ through 21 postpartum (Table 2; Figure 2). Some researchers have reported decreased plasma BHBA concentrations with PG administration (Studer et al., 1993; Grummer et al., 1994; Burhans et al., 1997).

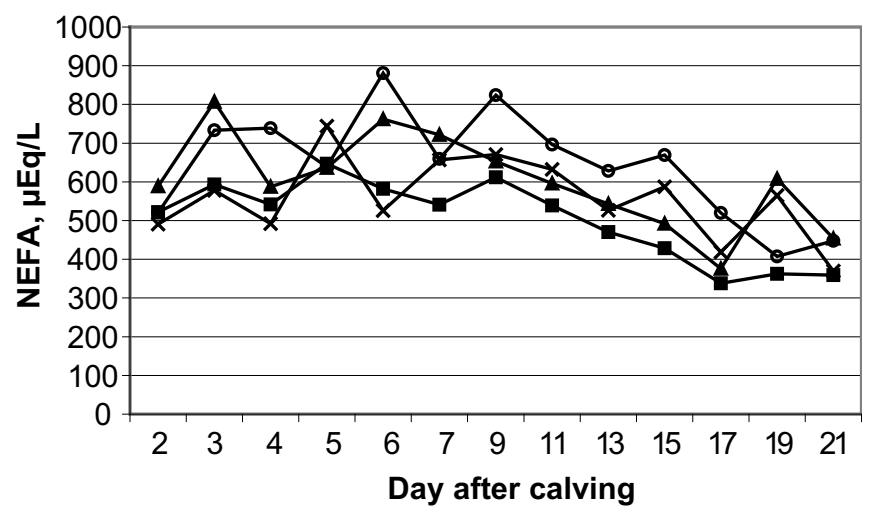

Figure 1. Least squares means for concentration of NEFA in plasma collected from cows administered an oral drench of $1.9 \mathrm{~L}$ of water (Control; $\bigcirc$ ), $500 \mathrm{ml}$ of propylene glycol (PG) brought to $1.9 \mathrm{~L}$ with water ( $\mathbf{\square}), 454 \mathrm{~g}$ rumen-protected fat mixed in $1.9 \mathrm{~L}$ of water $(\Delta)$, or the combination of $500 \mathrm{ml}$ of PG plus $454 \mathrm{~g}$ rumen-protected fat mixed in $1.9 \mathrm{~L}$ of water $(\times)$ for the first $3 \mathrm{~d}$ postpartum. Blood samples collected before calving served as covariates for statistical analysis (mean prepartum value $=111 \mu \mathrm{Eq} / \mathrm{L}$ ). Administration of PG tended $(P<0.07)$ to decrease concentrations of NEFA in plasma from d 2 through 7 and decreased $(P<0.03)$ concentrations of NEFA in plasma from d 2 through 21 postpartum. (Largest SEM $=99$ ). 


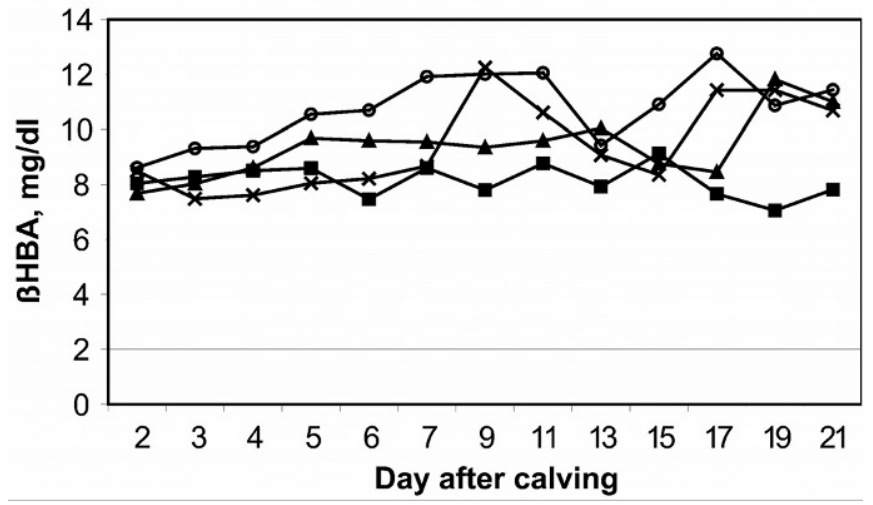

Figure 2. Least squares means for concentration of ( $\beta \mathrm{HBA})$ in plasma collected from cows administered an oral drench of $1.9 \mathrm{~L}$ of water (Control; O), $500 \mathrm{ml}$ of propylene glycol (PG) brought to $1.9 \mathrm{~L}$ with water $(\mathbf{\square}), 454 \mathrm{~g}$ rumen-protected fat mixed in $1.9 \mathrm{~L}$ of water (A), or the combination of $500 \mathrm{ml}$ of PG plus $454 \mathrm{~g}$ rumen-protected fat mixed in $1.9 \mathrm{~L}$ of water $(\times)$ for the first $3 \mathrm{~d}$ postpartum. Blood samples collected before calving served as covariates for statistical analysis (mean prepartum value $=6.7 \mathrm{mg} / \mathrm{dl}$ ). Administration of $\mathrm{PG}$ tended $(P<0.11)$ to decrease concentrations of BHBA in plasma from d 2 through 7 postpartum. There was a tendency for an interaction of PG, fat, and time $(P=0.11$; largest SEM $=1.7)$.

Other researchers have reported that PG administration did not affect concentrations of BHBA in plasma (Formigoni et al., 1996; Christensen et al., 1997; Stokes and Goff, 2001). Based on the lack of effect on BHBA in the other experiment that has been conducted using a short-term drench of PG (Stokes and Goff, 2001), we speculate that the short-term nature of our treatment administration may have limited our ability to affect concentrations of BHBA in outwardly healthy cows. Fat administration did not affect concentrations of BHBA in plasma during the first $21 \mathrm{~d}$ of lactation. Although the interaction of $\mathrm{PG}$ and fat was not significant for BHBA during d 2 through $21(P<0.22)$, we speculate that fat administration may somewhat blunt the response of BHBA and also NEFA to PG administration (Table 2).

In our experiment, there was an interaction of $\mathrm{PG}$ and fat for plasma glucose during both $\mathrm{d} 2$ through 7 postpartum $(P<0.04)$ and during d 2 through 21 postpartum $(P<0.03$; Table 2 ; Figure 3$)$. This interaction occurred because plasma concentrations of glucose were lower in cows administered control or PG+Fat treatments than those from cows administered PG or fat treatments alone. Plasma glucose concentrations were significantly increased (Studer et al., 1993; Grummer et al., 1994) or tended to increase (Christensen et al., 1997) with PG treatment in previous studies. Again, it appears as though concurrent administration of PG and fat decreased plasma glucose concentrations compared with administration of PG alone. The metabolic

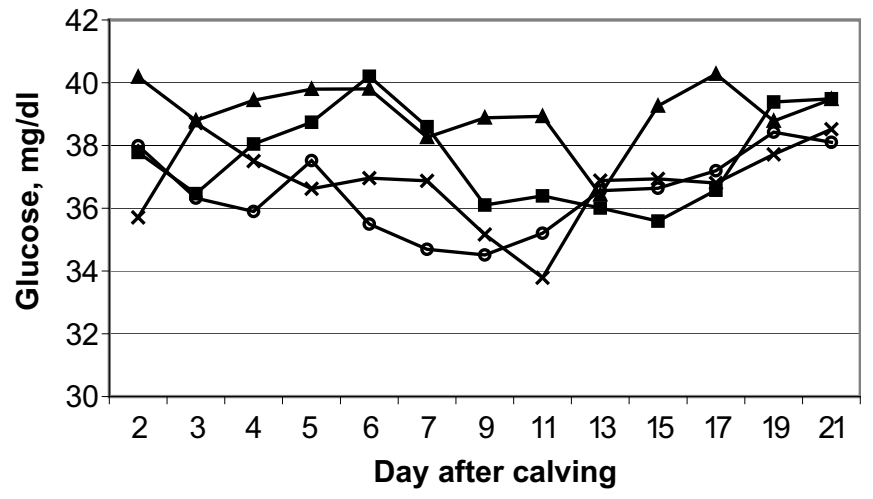

Figure 3. Least squares means for concentration of glucose in plasma collected from cows administered an oral drench of $1.9 \mathrm{~L}$ of water (Control; O), $500 \mathrm{ml}$ of propylene glycol (PG) brought to $1.9 \mathrm{~L}$ with water ( $), 454 \mathrm{~g}$ rumen-protected fat mixed in $1.9 \mathrm{~L}$ of water $(\boldsymbol{\Delta})$, or the combination of $500 \mathrm{ml}$ of PG plus $454 \mathrm{~g}$ rumen-protected fat mixed in $1.9 \mathrm{~L}$ of water $(\times)$ for the first $3 \mathrm{~d}$ postpartum. Blood samples collected before calving served as covariates for statistical analysis (mean prepartum value $=43.8 \mathrm{mg} / \mathrm{dl}$ ). There was an interaction of PG and fat administration during both $\mathrm{d} 2$ through $7(P<$ $0.04)$ and $\mathrm{d} 2$ through $21(P<0.03)$ postpartum. There was also a trend $(P<0.15)$ for an interaction of $\mathrm{PG}$ administration and time. (Largest SEM $=1.5)$.

reason underpinning this interaction is uncertain; however, it is supported by a comparable interaction for the concentrations of glycogen in liver from cows administered the four treatments.

Concentrations of insulin in plasma during either $\mathrm{d}$ 2 through 7 or $\mathrm{d} 2$ through 21 postpartum were not

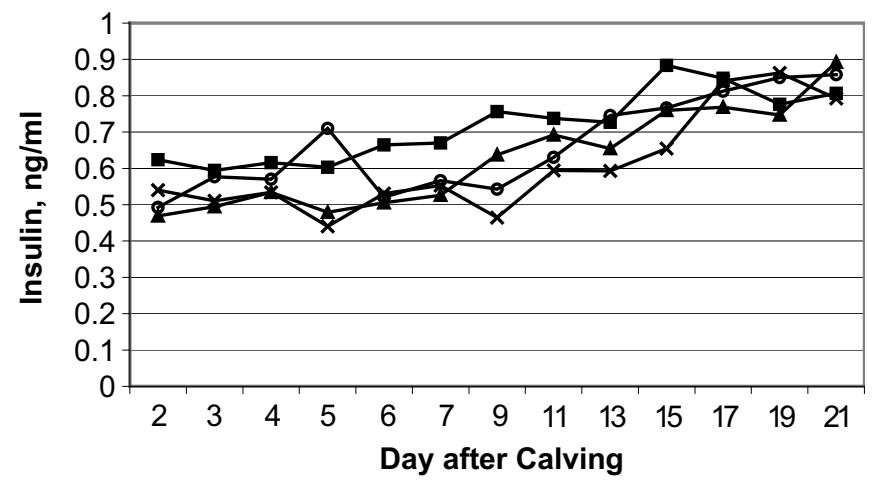

Figure 4. Least squares means for concentration of insulin in plasma collected from cows administered an oral drench of $1.9 \mathrm{~L}$ of water (Control; $\bigcirc), 500 \mathrm{ml}$ of propylene glycol (PG) brought to $1.9 \mathrm{~L}$ with water ( $), 454 \mathrm{~g}$ rumen-protected fat mixed in $1.9 \mathrm{~L}$ of water $(\boldsymbol{\Delta})$, or the combination of $500 \mathrm{ml}$ of PG plus $454 \mathrm{~g}$ rumen-protected fat mixed in $1.9 \mathrm{~L}$ of water $(\times)$ for the first $3 \mathrm{~d}$ postpartum. Blood samples collected before calving served as covariates for statistical analysis (mean prepartum value $=1.27 \mathrm{ng} / \mathrm{ml}$ ). There were no significant effects of treatment on concentrations of plasma insulin during either time period $(P>0.15)$ and treatment by time interactions were not significant $(P>0.15)$. (Largest $\mathrm{SEM}=0.10)$. 
Table 3. Least squares means and standard errors for liver composition on d 7 postpartum for cows administered a water control, propylene glycol (PG), fat, or a combination (PG+Fat) via oral drench during the first $3 \mathrm{~d}$ of lactation.

\begin{tabular}{|c|c|c|c|c|c|c|c|c|}
\hline \multirow[b]{2}{*}{ Item } & \multicolumn{4}{|c|}{ Treatment } & \multirow[b]{2}{*}{ SEM } & \multicolumn{3}{|c|}{ Effect, P } \\
\hline & Control & PG & Fat & $\mathrm{PG}+\mathrm{Fat}$ & & PG & Fat & $P G \times$ fat \\
\hline Triglyceride, \% wet wt & 10.8 & 6.1 & 10.0 & 10.0 & 2.0 & 0.20 & 0.41 & 0.21 \\
\hline Glycogen, mg/g wet wt & 10.1 & 16.7 & 12.7 & 8.9 & 3.0 & 0.62 & 0.36 & 0.07 \\
\hline
\end{tabular}

affected by treatment (Table 2; Figure 4). These data agree with results of Formigoni et al. (1996) where samples were obtained 30,60 , and 90 min postdrenching. In contrast, other researchers have reported increased concentrations of insulin when PG was administered (Studer et al., 1993; Grummer et al., 1994; Christensen et al., 1997). In these studies, blood was sampled several times over the few hours following PG treatment. Significant insulin responses were demonstrated to occur rapidly (within $15 \mathrm{~min}$ ) after PG treatment. In our study, blood was sampled at 24-h intervals immediately before the drench. Therefore, we would not expect to measure the acute surge in insulin concentrations reported in these studies. Furthermore, we would expect less potential for a sustained effect on insulin concentrations after cessation of the treatments.

Effects of treatment on hepatic TG content measured in samples collected on $\mathrm{d} 7$ postpartum were not significant (Table 3). Our results differ from a previous report (Studer et al., 1993), in which PG treatment before parturition significantly decreased hepatic TG accumulation at $d$ and 21 postpartum. The majority of triglyceride accumulation occurs by d 1 postpartum (Bertics et al., 1992; Vazquez-Anon et al., 1994). Because we did not commence administration of treatments until the day of calving, treatments would not have had the opportunity to impact this period of TG accumulation. After $\mathrm{d} 1$, rates of increase of liver TG content are slower. The $P$ values for $\mathrm{PG}$ administration $(P<0.20)$ and the interaction of $\mathrm{PG}$ and fat $(P<0.21)$ again suggest that fat administration may have blunted the ability of PG to decrease concentrations of TG in liver on d 7 postpartum. Fat administration did not affect concentrations of TG in liver (Table 3).
We detected a trend $(P<0.07)$ for an interaction of PG and fat for hepatic glycogen concentrations on $\mathrm{d} 7$ postpartum (Table 3). This interaction occurred because liver from cows administered PG alone had increased concentrations of glycogen in liver, but liver glycogen content decreased when PG was administered to cows also drenched with dietary fat. As noted above, cows administered the control and PG+Fat treatments also had lower concentrations of glucose in plasma as compared with the other two treatments. A comparison could not be made to previous research involving $\mathrm{PG}$ administration because none of these experiments reported concentrations of glycogen in liver. Glycogen is the storage form of carbohydrates in the liver and is mobilized to assist with the maintenance of glucose homeostasis. During ketosis induction through feed restriction and feeding 1,3-butanediol to provide ketone bodies, liver glycogen decreased significantly as hepatic TG accumulation increased (Veenhuizen et al., 1991).

We observed no effect of treatment on BW or BCS during the first $3 \mathrm{wk}$ of lactation (Table 4). Cows lost an average of approximately 0.22 BCS units between the prepartum period and wk 3 postpartum (3.53 vs. 3.31; data not shown). These results agree with a previous study that found no effect of PG treatment on BW or BCS (Studer et al., 1993).

Although our primary objective in this experiment was to assess metabolic responses to the administration of these treatments using a relatively small number of cows, we have reported the effects of the four treatments on DMI and milk yield and composition during the first $3 \mathrm{wk}$ of lactation in Table 5. Administration of PG did not affect weekly DMI, milk yield, or content and yield of milk components (Table 5). Our results

Table 4. Least squares means for BW and BCS during the first 3 wk postpartum for cows administered a water control, propylene glycol (PG), fat, or a combination (PG+Fat) via oral drench during the first $3 \mathrm{~d}$ of lactation.

\begin{tabular}{|c|c|c|c|c|c|c|c|c|}
\hline \multirow[b]{2}{*}{ Item } & \multicolumn{4}{|c|}{ Treatment } & \multirow[b]{2}{*}{ SEM } & \multicolumn{3}{|c|}{ Effect, $\mathrm{P}$} \\
\hline & Control & PG & Fat & PG+Fat & & PG & Fat & $\mathrm{PG} \times$ fat \\
\hline BW, kg & 609 & 596 & 601 & 602 & 7 & 0.34 & 0.92 & 0.26 \\
\hline $\mathrm{BCS}^{1}$ & 3.44 & 3.34 & 3.36 & 3.37 & 0.47 & 0.32 & 0.66 & 0.22 \\
\hline
\end{tabular}

${ }^{1} 1$ to 5 scale where $1=$ thin and $5=$ fat (Wildman et al., 1982). 
Table 5. Least squares means for DMI, milk yield, and milk composition during the first 3 wk of lactation for cows administered a water control, propylene glycol (PG), fat, or a combination (PG+Fat) via oral drench during the first $3 \mathrm{~d}$ of lactation.

\begin{tabular}{|c|c|c|c|c|c|c|c|c|}
\hline \multirow[b]{2}{*}{ Item } & \multicolumn{4}{|c|}{ Treatment } & \multirow[b]{2}{*}{ SEM } & \multicolumn{3}{|c|}{ Effect, $P$} \\
\hline & Control & PG & Fat & $\mathrm{PG}+\mathrm{Fat}$ & & PG & Fat & $\mathrm{PG} \times$ fat \\
\hline DMI, kg/d & 17.2 & 18.0 & 16.9 & 15.8 & 0.8 & 0.81 & 0.13 & 0.26 \\
\hline Milk yield, $\mathrm{kg} / \mathrm{d}$ & 36.5 & 36.1 & 32.5 & 34.8 & 1.8 & 0.59 & 0.12 & 0.45 \\
\hline Fat, \% & 4.66 & 4.30 & 4.64 & 4.66 & 0.16 & 0.29 & 0.29 & 0.25 \\
\hline Fat, $\mathrm{kg} / \mathrm{d}$ & 1.67 & 1.52 & 1.48 & 1.60 & 0.08 & 0.85 & 0.50 & 0.12 \\
\hline $3.5 \% \mathrm{FCM},{ }^{1} \mathrm{~kg} / \mathrm{d}$ & 42.9 & 40.3 & 38.1 & 40.9 & 2.0 & 0.95 & 0.30 & 0.18 \\
\hline True protein, \% & 3.68 & 3.46 & 3.66 & 3.51 & 0.19 & 0.36 & 0.95 & 0.87 \\
\hline True protein, kg/d & 1.33 & 1.20 & 1.14 & 1.20 & 0.09 & 0.70 & 0.32 & 0.33 \\
\hline
\end{tabular}

${ }^{1} 3.5 \% \mathrm{FCM}=0.4324(\mathrm{~kg}$ of milk $)+16.216(\mathrm{~kg}$ of fat $)$.

also agree with Studer et al. (1993) and Burhans et al. (1997), who reported no effect of PG administration on DMI, milk yield, and milk composition. In contrast, Stokes and Goff (2001) reported that milk yield of cows on a commercial dairy farm was increased by administration of PG on the first $2 \mathrm{~d}$ postpartum. In their experiment, they used substantially more cows per treatment $(\sim 40)$, which would have made for a more satisfactory statistical evaluation of the effects of treatment on milk yield.

Administration of fat tended to decrease both DMI $(P<0.13)$ and milk yield $(P<0.12)$ during the first $3 \mathrm{wk}$ postpartum (Table 5). When DMI data were analyzed using daily measurements, fat decreased $(P<0.03)$ DMI during $\mathrm{d} 2$ through 7 postpartum and tended $(P<0.06)$ to decrease DMI during $d 2$ through 21 postpartum (Figure 5). Daily milk yield during d 2 through 21

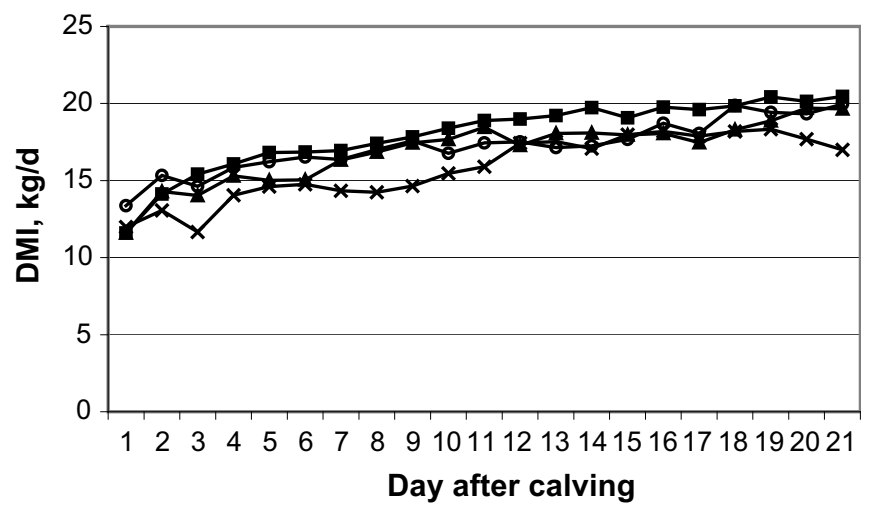

Figure 5. Least squares means for dry matter intake (DMI) of cows administered an oral drench of $1.9 \mathrm{~L}$ of water (Control; $\bigcirc$ ), 500 $\mathrm{ml}$ of propylene glycol (PG) brought to $1.9 \mathrm{~L}$ with water (匚), $454 \mathrm{~g}$ rumen-protected fat mixed in $1.9 \mathrm{~L}$ of water $(\mathbf{\Delta})$, or the combination of $500 \mathrm{ml}$ of PG plus $454 \mathrm{~g}$ rumen-protected fat mixed in $1.9 \mathrm{~L} \mathrm{of}$ water $(\times)$ for the first $3 \mathrm{~d}$ postpartum. The mean group DMI measured prepartum (21 d before expected calving) was $14.3 \mathrm{~kg} / \mathrm{d}$. Administration of fat decreased $(P<0.03)$ DMI during $\mathrm{d} 2$ through 7 postpartum $(15.4 \mathrm{vs} .14 .0 \mathrm{~kg} / \mathrm{d} ; \mathrm{SEM}=0.4)$ and tended $(P<0.06)$ to decrease DMI during d 2 through 21 postpartum (17.6 vs. $16.4 \mathrm{~kg} / \mathrm{d}$; SEM =0.5). (Largest SEM = 1.1) tended $(P<0.09)$ to be decreased by fat administration during the first $3 \mathrm{~d}$ postpartum (Figure 6 ). We are aware of no other data on administration of dietary fat as an oral drench and subsequent productive performance. There was a trend $(P<0.12)$ for an interaction of $P G$ and fat that resulted from cows administered control or PG+Fat treatments having higher yields of milk fat than cows administered PG or fat treatments alone. Although reasons for this interaction are not certain, it appears to be a result of a nonsignificant decrease in milk fat percentage when cows were administered $\mathrm{PG}$ alone combined with the lack of effect of PG on milk fat percentage of cows also administered fat.

The incidence of health disorders by cows administered the four treatments are reported in Table 6 . The number of cows per treatment in this experiment is insufficient to statistically assess these variables, and this information is reported for information only. In general, incidences of metabolic disorders were similar

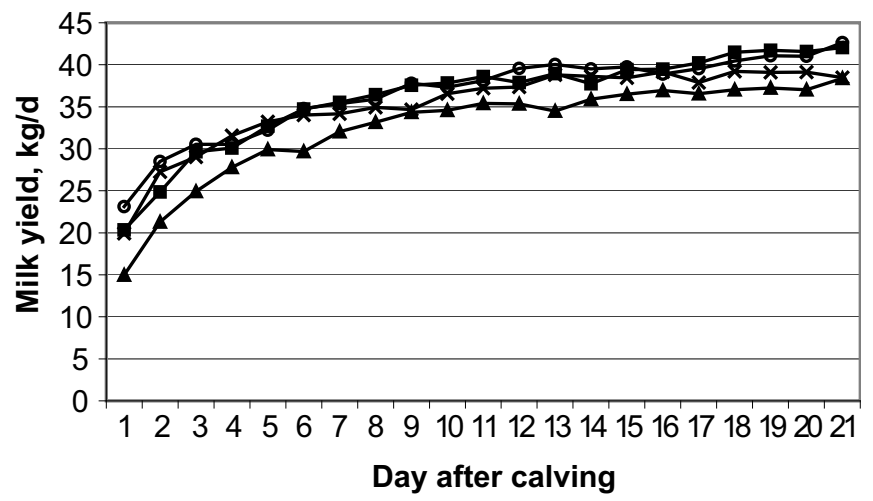

Figure 6. Least squares means for milk yield of cows administered an oral drench of $1.9 \mathrm{~L}$ of water (Control; $\bigcirc$ ), $500 \mathrm{ml}$ of propylene glycol (PG) brought to $1.9 \mathrm{~L}$ with water $(\mathbf{\square}), 454 \mathrm{~g}$ rumen-protected fat mixed in $1.9 \mathrm{~L}$ of water $(\boldsymbol{\Delta})$, or the combination of $500 \mathrm{ml}$ of PG plus $454 \mathrm{~g}$ rumen-protected fat mixed in $1.9 \mathrm{~L}$ of water $(x)$ for the first $3 \mathrm{~d}$ postpartum. Administration of fat tended $(P<0.09)$ to decrease milk yield from d 2 through 21 postpartum (36.3 vs. $33.9 \mathrm{~kg} /$ $\mathrm{d} ; \mathrm{SEM}=1.0)$. (Largest $\mathrm{SEM}=2.1$ ). 
Table 6. Incidence of health-related disorders during first $21 \mathrm{~d}$ of lactation in cows administered a water control, propylene glycol (PG), fat, or combination ( $\mathrm{PG}+\mathrm{Fat}$ ) via oral drench during the first $3 \mathrm{~d}$ of lactation.

\begin{tabular}{|c|c|c|c|c|c|c|c|c|}
\hline \multirow[b]{2}{*}{ Disorder } & \multicolumn{2}{|c|}{ Control } & \multicolumn{2}{|r|}{ PG } & \multicolumn{2}{|c|}{ Fat } & \multicolumn{2}{|c|}{$\mathrm{PG}+\mathrm{Fat}$} \\
\hline & \# cow & \# episodes & \# cow & \# episodes & \# cows & \# episodes & \# cows & \# episodes \\
\hline Twins & 1 & 1 & 3 & 3 & 0 & 0 & 0 & 0 \\
\hline Milk fever/slow rumen & 6 & 7 & 7 & 8 & 7 & 7 & 5 & 6 \\
\hline Retained placenta & 1 & 1 & 1 & 1 & 0 & 0 & 0 & 0 \\
\hline Displaced abomasum & 1 & 1 & 0 & 0 & 0 & 0 & 1 & 1 \\
\hline Ketosis & 2 & 2 & 2 & 2 & 2 & 2 & 4 & 4 \\
\hline Mastitis & 1 & 1 & 2 & 2 & 3 & 3 & 1 & 1 \\
\hline Digestive upset & 3 & 4 & 4 & 6 & 2 & 2 & 4 & 6 \\
\hline
\end{tabular}

across treatments, although the incidence of twin births was greater for cows assigned to the PG treatment. This could have slightly impacted overall treatment effects of PG in this experiment; however, we cannot determine this from our data. It should be noted that the staff of the Cornell Teaching and Research Center have employed an aggressive monitoring and treatment protocol, which has resulted in increased treatment of subjectively diagnosed disorders (i.e., milk fever/slow rumen, ketosis, digestive upset). Reported cases reflect primarily treatment of subclinical disorders; incidence of objectively diagnosed disorders (i.e., retained placenta, displaced abomasums) are relatively low.

\section{CONCLUSIONS}

Results from this study indicate that a short-term drenching strategy using PG effectively decreased concentrations of NEFA in plasma of cows during the first $21 \mathrm{~d}$ of lactation and tended to decrease concentrations of BHBA in plasma of cows during the first $7 \mathrm{~d}$ of lactation. Fat administration did not affect concentrations of metabolites and insulin in plasma and tended to decrease DMI and milk production. Furthermore, concurrent fat administration appeared to blunt the metabolic response to PG administration. Further research is required using larger numbers of cows to determine whether short-term drenching strategies with PG decreases incidence of metabolic disorders and increases milk production of dairy cows during early lactation.

\section{ACKNOWLEDGMENTS}

The partial financial assistance provided by Kevin Murphy of Bioproducts, Inc., is gratefully acknowledged. We also acknowledge Leo Richardson from Elanco Animal Health, Greenfield, IN, for gracious donation of the bovine insulin used in the insulin RIA. Sincere appreciation is extended to Matthew Waldron for assistance with treatment administration and sampling, Ramona Slepetis for assistance with laboratory analyses, and Mary Partridge, Tom Muscato, and the staff of the Cornell University Teaching and Research Center for helpful assistance in experiment management and care of the experimental animals.

\section{REFERENCES}

Bell, A. W. 1995. Regulation of organic nutrient metabolism during transition from late pregnancy to early lactation. J. Anim. Sci. 73:2804-2819.

Bertics, S. J., R. R. Grummer, C. Cadorniga-Valino, and E. E. Stoddard. 1992. Effect of prepartum dry matter intake on liver triglyceride concentration and early lactation. J. Dairy Sci. 75:19141922.

Burhans, W. S., E. A. Briggs, J. A. Rathmacher, and A. W. Bell. 1997. Glucogenic supplementation does not reduce body tissue protein degradation in periparturient dairy cows. J. Dairy Sci. 80(Suppl. 1):167. (Abstr.)

Christensen, J. O., R. R. Grummer, F. E. Rasmussen, and S. J. Bertics. 1997. Effect of method of delivery of propylene glycol on plasma metabolites of feed-restricted cattle. J. Dairy Sci. 80:563-568.

Drackley, J. K. 1999. Biology of dairy cows during the transition period: the final frontier? J. Dairy Sci. 82:2259-2273.

Drackley, J. K., T. R. Overton, and G. N. Douglas. 2001. Adaptations of glucose and long-chain fatty acid metabolism in liver of dairy cows during the periparturient period. J. Dairy Sci. 84(E. Suppl.):E100-E112.

Ehrhardt, R. A., R. M. Slepetis, A. W. Bell, and Y. R. Boisclair. 2001. Maternal leptin is elevated during pregnancy in sheep. Domest. Anim. Endocrinol. 21:85-96.

Emery, R. S., J. S. Liesman, and T. H. Herdt. 1992. Metabolism of long-chain fatty acids by ruminant liver. J. Nutr. 122:832-837.

Formigoni, A., M. Cornil, A. Prandi, A. Mordenti, A. Rossi, D. Portetelle, and R. Renaville. 1996. Effect of propylene glycol supplementation around parturition on milk yield, reproduction performance and some hormonal and metabolic characteristics in dairy cows. J. Dairy Res. 63:11-24.

Grummer, R. R. 1993. Etiology of lipid-related metabolic disorders in periparturient dairy cows. J. Dairy Sci. 76:3882-3896.

Grummer, R. R. 1995. Impact of changes in organic nutrient metabolism on feeding the transition dairy cow. J. Anim. Sci. 73:2820-2833.

Grummer, R. R., J. C. Winkler, S. J. Bertics, and V. A. Studer. 1994. Effect of propylene glycol dosage during feed restriction on metabolites in blood of prepartum Holstein heifers. J. Dairy Sci. 77:3618-3623.

Kronfeld, D. S. 1982. Major metabolic determinants of milk volume, mammary efficiency, and spontaneous ketosis in dairy cows. J. Dairy Sci. 65:2204-2212.

Littell, R. C., P. R. Henry, and C. B. Ammerman. 1998. Statistical analysis of repeated measures data using SAS procedures. J. Anim. Sci. 76:1216-1231.

Lo, S., J. C. Russell, and A. W. Taylor. 1970. Determination of glycogen in small tissue samples. J. Appl. Physiol. 28:234-236. 
McCutcheon, S. N., and D. E. Bauman. 1986. Effect of chronic growth hormone treatment on responses to epinephrine and thyrotropinreleasing hormone in lactating cows. J. Dairy Sci. 69:44-51.

Piepenbrink, M. S. 2003. Nutritional modulators of hepatic energy metabolism during the periparturient period of dairy cattle. $\mathrm{Ph} . \mathrm{D}$. Diss., Cornell Univ., Ithaca, NY.

Pullen, D. L., D. L. Palmquist, and R. S. Emery. 1989. Effect of days of lactation and methionine hydroxy analog on incorporation of plasma fatty acids into plasma triglycerides. J. Dairy Sci. 72:49-58.

Rukkwamsuk, T., T. A. M. Kruip, G. A. L. Meijer, and T. Wensing. 1999. Hepatic fatty acid composition in periparturient dairy cows with fatty liver induced by intake of a high energy diet in the dry period. J. Dairy Sci. 82:280-287.

SAS User's Guide: Statistics, Version 8 Edition. 2001. SAS Inst., Inc., Cary, NC.
Stokes, S. R., and J. P. Goff. 2001. Evaluation of calcium propionate and propylene glycol administered into the esophagus at calving. Prof. Anim. Sci. 17:115-122.

Studer, V. A., R. R. Grummer, S. J. Bertics, and C. K. Reynolds. 1993. Effect of prepartum propylene glycol administration on periparturient fatty liver in dairy cows. J. Dairy Sci. 76:29312939.

Vazquez-Anon, M., S. Bertics, M. Luck, R. Grummer, and J. Pinheiro. 1994. Peripartum liver triglyceride and plasma metabolites in dairy cows. J. Dairy Sci. 77:1521-1528.

Veenhuizen, J. J., J. K. Drackley, M. J. Richard, T. P. Sanderson, L. D. Miller, and J. W. Young. 1991. Metabolic changes in blood and liver during development and early treatment of experimental fatty liver and ketosis in cows. J. Dairy Sci. 74:4238-4253.

Wildman, E. E., G. M. Jones, P. E. Wagner, H. F. Troutt, Jr., and T. N. Lesch. 1982. A dairy cow body condition scoring system and its relationship to selected production characteristics. J. Dairy Sci. 65:495-501. 